\title{
Growth performance, feed utilisation and biological indices of Tra catfish (Pangasianodon hypophthalmus) cultured in net cages in pond fed diets based on locally available feed resources
}

\author{
Chau Thi Da $\cdot$ Torbjörn Lundh $\cdot$ Jan Erik Lindberg $\cdot$ Håkan Berg
}

Received: 1 December 2015/ Accepted: 15 September 2016/Published online: 26 September 2016

(C) The Author(s) 2016. This article is published with open access at Springerlink.com

\begin{abstract}
The feeding experiment was conducted to evaluate the efficacy of locally available feed resources for Tra catfish (Pangasianodon hypophthalmus) cultured a series of 21 hapa net cages installed in the earthen pond during a 4-month period. The reference diet contained fish meal as the main crude protein (CP) source, whilst in the seven test diets $20-100 \%$ of the fish meal CP was replaced with CP from local feed ingredients: groundnut cake (GNC), cassava leaf meal (CSLM), sweet potato leaf meal (SPLM), soybean meal (SBM), golden apple snail meal (GASM) and shrimp head meal. There were differences $(p<0.05)$ among diets in final body weight, total weight gain, daily weight gain, specific growth rate, viscera-somatic weight (VSI\%), hepato-somatic index (HIS\%) and intra-peritoneal fat (IPF\%). The respective values for the shrimp head meal diet were numerically highest, followed in descending order by the reference, GASM, GNC, SPLM, CSLM and SBM diet. Food conversion ratio, fish survival rate, total feed intake, feed utilisation, fish fillet and kidney proportions did not differ among the reference and test diets $(p>0.05)$. However, the viscera-somatic, hepato-somatic, kidney and intra-peritoneal fat indices differed among treatments $(p<0.05)$. These data show that fish meal protein can be replaced with protein from locally available plant and animal feed ingredient resources in feed cultured in net cages in pond for Tra catfish fingerlings in effectively compromising growth performance, feed utilisation or carcass traits of fish.
\end{abstract}

Keywords Fish meal protein · Local feed resources · Tra catfish · Earthen pond-cultured · Happa-net cages

\section{Introduction}

The Tra catfish (Pangasianodon hypophthalmus) farming system in the Mekong Delta of Vietnam is still operated by many small-scale farmers but with increasing pressure from large-scale operators (Bui et al. 2010; Phan et al. 2009; De Silva and Phuong 2011). The catfish farming sector operates at marginal profit levels and

\footnotetext{
C. T. Da (西)

Department of Aquaculture, Faculty of Agriculture and Natural Resources, An Giang University, 18 Ung Van Khiem Street,

Dong Xuyen Wards, Long Xuyen, Vietnam

e-mail: chau.thida@gmail.com; ctda@agu.edu.vn

T. Lundh $\cdot$ J. E. Lindberg

Department of Animal Nutrition and Management, Swedish University of Agricultural Sciences, P. O. Box 7024,

75007 Uppsala, Sweden

H. Berg

Department of Physical Geography, Stockholm University, 10691 Stockholm, Sweden
} 
the long-term viability of the industry will be determined by the operation costs of grow-out farms and the farm gate price of the farmed fish (Phan et al. 2009; De Silva and Phuong 2011). A large proportion of the operation costs consists of feed costs, which are estimated to account for 70-90\% of total investment costs (Da et al. 2011; Hung et al. 2007; Phuong et al. 2007). The replacement of fish meal and trash fish (marine origin) would simply reduce the required input of the most expensive ingredients in fish feeds and thereby reduce the investment costs and increase the profit level for the farmers. This would also decrease the dependence and pressure on wild fish populations used for fishmeal. In Southern Vietnam, many potential "trash fish" species are currently used for fish sauce production and other human uses of high nutritional and economic values (Edwards et al. 2004; Loc et al. 2010).

The increasing volume of exports has to be met with an increase in the fish production, quantity and quality of feeds (De Silva and Phuong 2011). Because of its high nutritional value and palatability, fish meal and trash fish (marine origin) still remain the major dietary protein sources for striped catfish, comprising $20-60 \%$ of the feed. However, using fish meal in fish feed is not a sustainable long-term feeding strategy (Naylor et al. 2009; FAO 2010). It is estimated that in order to produce 1.2 million tonnes of Tra catfish about 1.4 million tonnes wild-caught whole fish will be required as feed (Halls and Johns 2013; Mamat and Alfaro 2014). This reliance on wild marine fish in this aquaculture industry sector constitutes a major vulnerability of declining stocks of wild marine fish therefore more works are needed to identify the alternative fishmeal from local feed resources for this fish species (Kader et al. 2010).

Tra catfish is an omnivorous fish (Phuong 1998; Cacot and Pariselle 1999) and capable of using a wide range of protein sources efficiently. The Mekong Delta contains several locally available alternative protein feed sources that are abundant and have nutritional properties indicating that they could potentially be useful as ingredients in striped catfish feed (Da et al. 2011). Earlier studies have shown that soybean meal can be used in striped catfish feed as a replacement for fish meal without any negative effects on growth performance and carcass traits (Phumee et al. 2011; Hung et al. 2003). Da et al. (2012) also reported that earlier results of laboratory study, fish meal protein in feed for Tra catfish fingerlings can be replaced with protein from locally available feed resources in effectively compromising on growth performance, feed utilisation or carcass traits. However, that study and most other previous studies have evaluated that feed sources for cultured fish have been performed under controlled indoor conditions with clean water. Such an experimental model is very different from the conditions under which striped catfish are cultured on earthen pond farming systems in the Mekong Delta, using water from the rivers and canals (Da et al. 2011). The river and canal water contain dissolved nutrients and various living organisms (such as zooplankton, algae and invertebrates), which under pond conditions grow and contribute more or less to the nutrient supply of the cultured fish. Therefore, the fish response to a feed ingredient cultured in an earthen pond farming system may be different from that obtained under controlled indoor conditions with clean water. The hypothesis tested in this study was that fish growth performance and feed utilisation are better in earthen pond-cultured than indoor-cultured Tra catfish and the fish in this experiment was not feed on natural foods. This study evaluated the growth performance, feed utilisation and carcass traits of Tra catfish cultured in hapa net cages installed in earthen pond fed diets where fish meal protein was replaced with protein from groundnut cake (GNC), cassava leaf meal (CSLM), sweet potato leaf meal (SPLM), soybean meal (SBM), golden apple snail meal (GASM) and shrimp head meal (SHM).

\section{Materials and methods}

Study site

The study was carried out in an earthen pond at the Faculty of Agriculture and Natural Resources, An Giang University, An Giang province in the Mekong Delta of Vietnam.

Experimental diets

The experimental diets, consisting of one reference diet and six test diets, were formulated to meet the nutrient requirements of Tra catfish (Hung et al. 2002). The reference diet contained fish meal as the main crude 
protein $(\mathrm{CP})$ source, whilst in the six test diets $20-100 \%$ of the fish meal CP was replaced with CP from alternative local ingredients (Table 1).

Experimental fish

Tra catfish (Pangasianodon hypophthalmus) fingerlings were bought from the Research Center of Aquaculture Seed Production in An Giang province. The fish were treated with a $3 \% \mathrm{NaCl}$ solution for $15 \mathrm{~min}$ on arrival to eliminate ectoparasite infection, and were reared and quarantined in a hapa net cage $(4 \times 8 \mathrm{~m} \times 2 \mathrm{~m})$ in an earthen pond for 2 weeks to acclimatise to the hapa net cage conditions. Fish were then randomly selected from the rearing, weighed and transferred to the experimental hapa net cage $(2 \mathrm{~m} \times 3 \mathrm{~m} \times 2 \mathrm{~m}) 1$ week before the experiment commenced for acclimatisation to experimental conditions.

Experimental design

The experiment was set up as a factorial design with seven different diets fed in triplicate groups of Pangasius fingerlings reared in hapa net cages in earthen pond for 4 months. At the beginning and end of the experiment, fish were individually weighed using a digital scale. One-hundred and seventy-five homogeneous fish with an average initial body weight (BW) of $16.5 \pm 0.1 \mathrm{~g} /$ fish were selected and distributed into each hapa net cage for each treatment.

Test feed ingredients

The chemical composition of the test feed ingredients is shown in Table 2. Groundnut cake was purchased from Vinh Long province and shrimp head meal from Kien Giang province. Soybean meal (India) and Kien Giang fish meal were purchased from the local market (AFIEX plant) in Long Xuyen city, An Giang province. Cassava leaves and sweet potato leaves (both stem and leaf) were collected during the harvest period from

Table 1 Ingredient composition of reference diet (RD) and test diets $(\mathrm{g} / \mathrm{kg})$ for Tra catfish (Pangasianodon hypophthalmus) fingerlings

\begin{tabular}{|c|c|c|c|c|c|c|c|}
\hline \multirow[t]{2}{*}{ Treatment } & \multirow[t]{2}{*}{$\mathrm{RD}$} & \multicolumn{6}{|l|}{ Test diets } \\
\hline & & $\begin{array}{l}\text { Ground- } \\
\text { nut cake }\end{array}$ & $\begin{array}{l}\text { Cassava } \\
\text { leaf meal }\end{array}$ & $\begin{array}{l}\text { Sweet potato } \\
\text { leaf meal }\end{array}$ & $\begin{array}{l}\text { Soy-bean } \\
\text { meal }\end{array}$ & $\begin{array}{l}\text { Golden apple } \\
\text { snail meal }\end{array}$ & $\begin{array}{l}\text { Shrimp } \\
\text { head meal }\end{array}$ \\
\hline Fish meal & 260 & 195 & 195 & 208 & 0.0 & 0.0 & 0.0 \\
\hline Vegetable protein $\operatorname{mix}^{\mathrm{a}}$ & 480 & 480 & 400 & 400 & 450 & 480 & 480 \\
\hline Wheat flour & 200 & 200 & 200 & 200 & 200 & 220 & 260 \\
\hline Squid liver oil & 20 & 20 & 20 & 20 & 20 & 20 & 20 \\
\hline Vit-min premix $^{b}$ & 20 & 20 & 20 & 20 & 20 & 20 & 20 \\
\hline $\mathrm{CMC}^{\mathrm{c}}$ & 20 & 20 & 20 & 20 & 20 & 20 & 20 \\
\hline Groundnut cake & - & 65 & - & - & - & - & - \\
\hline Cassava leaf meal & - & - & 145 & - & - & - & - \\
\hline Sweet potato leaf meal & - & - & - & 132 & - & - & - \\
\hline Soybean meal & - & - & - & - & 290 & - & - \\
\hline Golden apple snail meal & - & - & - & - & - & 240 & - \\
\hline Shrimp head meal & - & - & - & - & - & - & 200 \\
\hline $\begin{array}{l}\text { Rate of replacement of fish } \\
\text { meal (FM) (\%) }\end{array}$ & 0 & 25 & 25 & 20 & 100 & 100 & 100 \\
\hline
\end{tabular}

${ }^{a}$ Commercial product used for Tra catfish feed in the Mekong Delta of Vietnam. The product is based on soybean and rice products and contains (93.2\% of DM): CP $21.2 \%$, EE $7.6 \%$, NDF $25.5 \%$, ash $3.1 \%$

b Vitamin and mineral premix; content per kg: vitamin A 4,000,000 UI; vitamin D3 800,000 UI; vitamin E 8500 UI; vitamin K3 750 UI; vitamin B1 375 UI; vitamin C 8750 UI; vitamin B2 1600 mg; vitamin B6 750 mg; folic acid 200 mg; vitamin B12 3000 $\mathrm{mcg}$; biotin 20,000 mcg; methionine $2500 \mathrm{mg}$; Mn, Zn, Mg, K and $\mathrm{Na} 10 \mathrm{mg}$

c Carboxymethyl cellulose (CMC): imported from Korea 
Table 2 Chemical composition $(\mathrm{g} / \mathrm{kg} \mathrm{DM})$, gross energy $(\mathrm{MJ} / \mathrm{kg} \mathrm{DM})$ and essential amino acid $(\mathrm{g} / \mathrm{kg}$ DM) content of test ingredients

\begin{tabular}{|c|c|c|c|c|c|c|}
\hline & $\begin{array}{l}\text { Groundnut } \\
\text { cake }\end{array}$ & $\begin{array}{l}\text { Cassava leaf } \\
\text { meal }\end{array}$ & $\begin{array}{l}\text { Sweet potato leaf } \\
\text { meal }\end{array}$ & $\begin{array}{l}\text { Soybean } \\
\text { meal }\end{array}$ & $\begin{array}{l}\text { Golden apple snail } \\
\text { meal }\end{array}$ & $\begin{array}{l}\text { Shrimp head } \\
\text { meal }\end{array}$ \\
\hline Crude protein & 316 & 223 & 166 & 485 & 564 & 661 \\
\hline Lipid & 100 & 65 & 24 & 10 & 16 & 36 \\
\hline Crude fibre & 41 & 145 & 14 & 35 & 10 & 61 \\
\hline $\mathrm{NDF}$ & 342 & 339 & 397 & 198 & 239 & 242 \\
\hline Ash & 55 & 97 & 170 & 73 & 118 & 143 \\
\hline Gross energy & 19.5 & 18.9 & 14.6 & 17.8 & 12.3 & 16.6 \\
\hline \multicolumn{7}{|c|}{ Essential amino acids } \\
\hline Arginine & 27.9 & 11.1 & 7.7 & 24.9 & 32.1 & 38.2 \\
\hline Histidine & 5.0 & 3.4 & 1.9 & 4.8 & 11.9 & 11.1 \\
\hline Isoleucine & 12.0 & 10.7 & 7.5 & 18.3 & 18.8 & 20.9 \\
\hline Leucine & 19.8 & 17.2 & 10.9 & 29.1 & 36.2 & 37.2 \\
\hline Lysine & 5.2 & 6.7 & 2.6 & 15.1 & 16.3 & 25.5 \\
\hline Methionine & 4.0 & 5.2 & 4.3 & 6.4 & 10.9 & 14.5 \\
\hline Phenylalanine & 13.8 & 10.6 & 7.6 & 18.6 & 16.4 & 19.0 \\
\hline Threonine & 6.7 & 8.4 & 5.0 & 14.2 & 11.1 & 9.0 \\
\hline Valine & 13.6 & 11.5 & 8.7 & 18.3 & 20.8 & 19.3 \\
\hline Total & 108.0 & 84.8 & 56.2 & 149.7 & 174.5 & 194.7 \\
\hline
\end{tabular}

farms in the Tri Ton and Cho Moi districts of An Giang province, respectively. The leaves were cleaned with freshwater, sun dried for 2-3 days and then milled to a meal. Golden apple snails were purchased from farmers in Cho Moi district, An Giang province, and Tam Nong district, Dong Thap province. Only the meat of the golden apple snails was collected and it was cleaned with freshwater and sun dried for 3 days before use.

Diet preparation and feeding

The feed was produced by mixing the dry ingredients carefully and then adding squid oil and distilled water. The amount of distilled water was adjusted to get the mixture to form a stiff dough. The pelleted feed was made using an electronic meat grinder (Quoc Hung company, Vietnam), with diameter and length of pelleted feed in the range 1-2 $\mathrm{mm}$. All diets were sun dried for 2-3 days and then weighed and stored in sealed plastic bags in small portions at $5{ }^{\circ} \mathrm{C}$ until use. New batches of experimental feeds were made bi-weekly. The fishes were fed by hand to apparent satiety, at a rate of about 3-5\% body weight per day, at 9.00 and $14.00 \mathrm{~h}$.

Experiment system and management

The experiment was carried out in a $700 \mathrm{~m}^{2}$ earthen pond with a depth of $2 \mathrm{~m}$. A series of 21 hapa net cages with $2.0 \mathrm{~mm}$ mesh size were placed in the pond and were used to hold the fish. The hapa net cages were rectangular $(2 \times 3 \mathrm{~m} \times 2 \mathrm{~m}$ deep $)$ and were suspended by tying them to four melaleuca poles. One feeding sieve (feeding trap), $30 \mathrm{~cm}$ in diameter, was placed in each hapa net cage to retain feed and to prevent feed falling to the bottom. The feed was distributed to each feeding sieve using a small boat. All feeding sieves and happa net cages were scrubbed and cleaned monthly to remove moss and muddy slime from the mesh. The pond was prepared before the experiment by removing wastewater and pond sediments and left empty to dry for about 2 weeks. The bottom sediments of the pond were treated with 30-40 kg lime and left to dry for a week before river water was pumped into the pond. About $20 \%$ of the water in the pond was replaced by new water from the river every 2 weeks during the experiment. 
Chemical analysis

Samples of feed ingredients, diets and fish fillets, liver and kidney were analysed in duplicate using standard methods (AOAC 1997). Dry matter was determined by drying in an oven at $105{ }^{\circ} \mathrm{C}$ for $24 \mathrm{~h}$. Nitrogen (N) was determined by the Kjeldahl method and crude protein $(\mathrm{CP})$ was calculated as $\mathrm{N} \times 6.25$. Crude fat (EE) content was analysed using the Soxhlet method after acid hydrolysis of the sample. Crude fibre (CF) content was determined by standard methods (AOAC 1997) and neutral detergent fibre (NDF) was determined according to Van Soest et al. (1991). Ash content was determined by incineration in a muffle furnace at $550{ }^{\circ} \mathrm{C}$ for $12 \mathrm{~h}$. Amino acid content of ingredients and diets was analysed by high-performance liquid chromatography according to Vázquez-Ortiz et al. (1995). Gross energy $\left(\mathrm{MJ} \mathrm{kg}^{-1}\right)$ was determined with a bomb calorimeter (Calorimeter Parr 6300, Parr Instrument Company, Moline, IL, USA).

Water quality monitoring

Temperature $\left(T^{\circ} \mathrm{C}\right)$ was recorded daily with a temperature meter at 8.00 and $14.00 \mathrm{~h}$. Dissolved oxygen (DO $\mathrm{mg} / \mathrm{L}$ ), chemical oxygen demand (COD $\mathrm{mg} / \mathrm{L}$ ) and biochemical oxygen demand (BOD $\mathrm{mg} / \mathrm{L}$ ) parameters were measured twice a month; all water samples for COD and BOD were carefully taken from fish pond and filled into a 300-mL glass of biological oxygen demand (BOD). And then the water sample in glass BOD was immediately added $2 \mathrm{~mL}$ of manganese sulfate and was analyzed in laboratory (Stirling 1985). COD and BOD $\mathrm{mg} / \mathrm{L}$ parameters were measured using the Hach Lange cuvett test method (DR2800 visual spectrophotometer, Hach Lange Gmbh, Germany).

Water samples of Nitrite nitrogen $\left(\mathrm{NO}_{2} \mathrm{mg} / \mathrm{L}\right)$, nitrate nitrogen $\left(\mathrm{NO}_{3} \mathrm{mg} / \mathrm{L}\right)$, total ammonia-nitrogen (TAN $\mathrm{mg} / \mathrm{L}$ ) parameter were collected twice a month. Water samplings were surrounded by ice and measured in laboratory using the Hach Lange cuvett test method (DR2800 visual spectrophotometer, Hach Lange Gmbh, Germany). The $\mathrm{pH}$ was recorded twice a month in the fish pond with a $\mathrm{pH}$ meter (Schott Greate, Florida, USA). Plankton species in the pond water were monitored and determined twice a month as described by Bellinger and Sigee (2010). The density of plankton was calculated by the formula: $N=(P \times C \times 100) / V$, where $N$ is the number of plankton per litre of water in the pond, $P$ is the number of planktonic organisms counted in different hapa net cages of different treatments, $C$ is the volume of the plastic bottle holding the sample $(100 \mathrm{~mL})$ and $V$ is the volume of water sample from each hapa net cage. The identification of zooplankton and phytoplankton species was based on Suthers and Rissik (2008).

Fish sampling for body indices calculation

Six-hundred and thirty fish (30 fish/hapa net) were randomly collected at the end of experiment. The fillet, kidney, liver, fat and carcass of fish were individually weighed using a digital scale for body indices calculation of the percentage of fillet, viscera-somatic (VSI\%), hepato-somatic (HSI\%), kidney and intra-peritoneal fat (IPF\%) index.

Calculations

The following calculations were made:

The specific growth rate $(\mathrm{SGR} \%)=\left[\left(\ln W_{\mathrm{f}}-\ln W_{\mathrm{i}}\right) / T\right] \times 100$ and daily weight gain $(\mathrm{DWG})=\left(W_{\mathrm{f}}--\right.$ $\left.W_{\mathrm{i}}\right) / T$ ), where $W_{\mathrm{f}}$ and $W_{\mathrm{i}}$ refer to the mean final weight and the mean initial weight, respectively, and $T$ is the feeding trial period in days.

Survival rate $\left[(\mathrm{SR} \%)=\left(\mathrm{TF}_{\mathrm{f}} / \mathrm{TF}_{\mathrm{i}}\right) \times 100\right]$, where $\mathrm{TF}_{\mathrm{f}}$ is the total number of fish at finish (harvest) and $\mathrm{TF}_{\mathrm{i}}$ is the total number of fish at start.

Protein efficiency ratio $(\mathrm{PER})=$ wet weight gain $(\mathrm{g}) /$ total protein intake $(\mathrm{g})$.

Protein intake $(\mathrm{PI})=$ feed intake $(\mathrm{g}) \times$ percent protein in diet.

Total feed intake per fish $(\mathrm{FI})=[$ total feed intake $(\mathrm{g}) /$ number of fish $]$.

Feed conversion ratio $(\mathrm{FCR})=[$ total feed intake $(\mathrm{g}) /$ total wet weight gain $(\mathrm{g})]$.

Hepato-somatic index $(\mathrm{HSI} \%)=[100 \times($ liver weight $(\mathrm{g}) /$ body weight $(\mathrm{g}))]$. 
Intra-peritoneal fat $(\mathrm{IPF} \%)=[100 \times($ intra-peritoneal fat weight $(\mathrm{g}) /$ body weight $(\mathrm{g}))]$.

Viscera-somatic weight $($ VSI\% $)=[100 \times($ viscera-somatic weight $(\mathrm{g}) /$ body weight $(\mathrm{g}))]$.

Kidney index $(\mathrm{KI})=[100 \times($ kidney weight $(\mathrm{g}) /$ body weight $(\mathrm{g}))]$.

\section{Statistical analysis}

All data on fish growth performance, feed utilisation and carcass traits were statistically analysed by one-way analysis of variance (ANOVA), using Tukey's post hoc ANOVA test for individual comparisons $(p \leq 0.05$ level of significance). All statistical analysis was carried out using the IBM SPSS STATISTIC (Ibm 2011) programme, version 19.

\section{Results}

Chemical composition of feed ingredients and diets

The CP content of feed ingredients was highest in shrimp head meal, followed in descending order by golden apple snail meal, soybean meal, groundnut cake, cassava leaf meal and sweet potato leaf meal (Table 2).

The EE content was highest in groundnut cake, followed by cassava leaf meal and shrimp head meal, whilst the content of CF and NDF showed different patterns among feed ingredients. The highest CF and ash content were found in cassava leaf meal and shrimp head meal, whilst the highest NDF content was found in sweet potato leaf meal, groundnut cake and cassava leaf meal. The gross energy content varied between feed ingredients within the range 12.3-19.5 MJ/kg, with the lowest value in golden apple snail meal and the highest in groundnut cake. The essential amino acid (EAA) profile varied between feed ingredients (Table 2). In general, the most individual EAA was lowest in sweet potato leaf meal and cassava leaf meal. In contrast, shrimp head meal, golden apple snail meal and soybean meal were high in most EAA.

Table 3 Chemical composition $(\mathrm{g} / \mathrm{kg} \mathrm{DM})$, and gross energy $(\mathrm{MJ} / \mathrm{kg} \mathrm{DM})$ and amino acid $(\mathrm{g} / \mathrm{kg} \mathrm{DM})$ content of the reference diet (RD) and test diets

\begin{tabular}{|c|c|c|c|c|c|c|c|}
\hline \multirow{2}{*}{$\begin{array}{l}\text { Chemical } \\
\text { composition }\end{array}$} & \multirow[t]{2}{*}{ RD } & \multicolumn{6}{|c|}{ Test diets (\% of fish meal crude protein replaced) } \\
\hline & & $\begin{array}{l}\text { Ground-nut } \\
\text { cake }(25 \%)\end{array}$ & $\begin{array}{l}\text { Cassava leaf } \\
\text { meal }(25 \%)\end{array}$ & $\begin{array}{l}\text { Sweet potato } \\
\text { leaf meal }(20 \%)\end{array}$ & $\begin{array}{l}\text { Soybean } \\
\text { meal } \\
(100 \%)\end{array}$ & $\begin{array}{l}\text { Golden apple snail } \\
\text { meal }(100 \%)\end{array}$ & $\begin{array}{l}\text { Shrimp head } \\
\text { meal }(100 \%)\end{array}$ \\
\hline Crude protein & 225 & 230 & 227 & 223 & 234 & 227 & 225 \\
\hline Lipid & 45 & 39 & 44 & 38 & 35 & 31 & 35 \\
\hline Crude fibre & 29 & 45 & 51 & 51 & 37 & 53 & 59 \\
\hline $\mathrm{NDF}$ & 166 & 242 & 261 & 278 & 201 & 253 & 259 \\
\hline Ash & 102 & 81 & 73 & 84 & 41 & 41 & 89 \\
\hline Gross energy & 16.2 & 16.7 & 17.1 & 16.5 & 17.2 & 16.8 & 15.9 \\
\hline \multicolumn{8}{|c|}{ Essential amino acids } \\
\hline Arginine & 14.8 & 14.7 & 13.4 & 13.2 & 13.7 & 14.6 & 14.7 \\
\hline Histidine & 6.4 & 5.6 & 5.5 & 5.5 & 3.2 & 4.8 & 4.2 \\
\hline Isoleucine & 9.7 & 9.3 & 9.3 & 9.0 & 10.2 & 9.7 & 9.5 \\
\hline Leucine & 17.6 & 16.6 & 16.6 & 16.0 & 16.5 & 17.3 & 16.3 \\
\hline Lysine & 9.3 & 8.0 & 8.2 & 7.9 & 6.9 & 6.6 & 7.8 \\
\hline Methionine & 5.9 & 5.3 & 5.4 & 5.4 & 4.0 & 4.9 & 5.3 \\
\hline Phenylalanine & 9.8 & 9.7 & 9.5 & 9.1 & 10.6 & 9.6 & 9.6 \\
\hline Threonine & 6.3 & 6.1 & 6.3 & 5.8 & 7.7 & 6.6 & 5.7 \\
\hline Valine & 10.5 & 10.1 & 10.1 & 9.8 & 10.5 & 10.5 & 9.5 \\
\hline Total & 90.3 & 85.4 & 84.3 & 81.7 & 83.3 & 84.6 & 82.6 \\
\hline
\end{tabular}


The chemical composition, gross energy content and EAA profiles of experimental diets were similar amongst diets with 223-230 g CP/kg, 15.9-17.2 MJ GE/kg and 81.7-90.3 g total EAA/kg (Table 3).

Growth performance and feed utilisation

There were differences ( $p=0.01-0.03$ ) between diets in final body weight (BW), total weight gain (WG), daily weight gain (DWG) and specific growth rate (SGR) (Table 4).

The highest final BW, total WG, DWG and SGR were recorded for the shrimp head meal diet, followed in descending order by the golden apple snail meal and groundnut cake diets, the sweet potato leaf meal and cassava leaf meal diets and finally the soybean meal diet. The growth performance traits of fish on the shrimp head meal diet did not differ $(p>0.05)$ from those on the reference diet (Table 4). Fish fed shrimp head meal, groundnut cake and golden apple snail meal had a lower PI $(p>0.23)$ than fish on diets with soybean meal, cassava leaf meal or sweet potato leaf meal. There were no differences $(p>0.05)$ in FI, PER, FCR, PI between fish fed the reference diet and the diets with shrimp head meal, golden apple snail meal, groundnut cake, cassava leaf meal, sweet potato leaf meal and soybean meal (Table 4). The survival rates were high (range 90.5-96.3\%) and did not differ between treatments $(p>0.05)$.

Carcass and body indices

The proportion of fish fillet and kidney at the end of experiment ranged from (34.7-38.4\%) to (0.7-0.9 \%) (wet weight basis), respectively, but there were no differences between the reference diet and the other diets $(p>0.05)$ (Table 5). The viscera-somatic index (VSI\%), hepato-somatic index (HSI\%) and (IPF\%) index differed between treatments, with the highest VSI and HSI\% $(p<0.05)$ for golden apple snail meal and shrimp head meal diets. The highest content of intra-peritoneal fat (IPF\%) was recorded for the soybean meal, golden apple snail meal and shrimp head meal diets $(p<0.001)$.

The chemical composition of fillet, kidney and liver did not differ between the reference diet and the test diets $(p>0.05)$. The highest CP content was found in the fish fillet $(151-171 \mathrm{~g} / \mathrm{kg})$, followed in descending order by liver $(142-159 \mathrm{~g} / \mathrm{kg}$ ) and kidney $(139-155 \mathrm{~g} / \mathrm{kg})$. The highest lipid content was found in liver $(52-101 \mathrm{~g} / \mathrm{kg})$ and the lowest in kidney (range 10-36 g/kg) $(p<0.05)$. There were no differences $(p>0.05)$ in ash content between fillet, kidney and liver.

Water quality

Average temperature $\left({ }^{\circ} \mathrm{C}\right.$ ) was $28.6 \pm 0.9$ (range 27.2-30.1), $\mathrm{pH}$ was $7.8 \pm 1.0(6.7-8.2)$ and DO content $(\mathrm{mg} / \mathrm{L})$ was $7.0 \pm 1.0(5.4-7.2)$. Total ammonia nitrogen (TAN), total nitrogen $(\mathrm{TN})$ and total phosphorous (TP) were low during the experiment, with TAN $(\mathrm{mg} / \mathrm{L})$ of $0.4 \pm 0.2(0.1-0.8), \mathrm{TN}(\mathrm{mg} / \mathrm{L})$ of $0.8 \pm 0.21$ $(0.5-1.0)$ and $\mathrm{TP}(\mathrm{mg} / \mathrm{L}) 0.6 \pm 0.2(0.2-0.9)$. Nitrite $\left(\mathrm{NO}_{2}\right)$ and nitrate $\left(\mathrm{NO}_{3}\right)$ were also low during the experiment, with $\mathrm{NO}_{2}(\mathrm{mg} / \mathrm{L})$ of $0.1 \pm 0.02(0.03-0.1)$ and $\mathrm{NO}_{3}(\mathrm{mg} / \mathrm{L})$ of $0.07 \pm 0.01(0.01-0.1)$. The chemical oxygen demand (COD) $(\mathrm{mg} / \mathrm{L})$ was $43.4 \pm 12.7$ (22-69) and the biochemical oxygen demand (BOD) $(\mathrm{mg} / \mathrm{L})$ was $19.8 \pm 7.5(11-32)$. The concentration of total suspended solids $(\mathrm{TSS})(\mathrm{mg} / \mathrm{L})$ was $251.2 \pm 59.9(115.6-356)$.

Plankton monitoring and assessment

\section{Phytoplankton}

Four phyla of micro algae: Chlorophyta (green-algae), Cyanophyta (blue-green algae), Bacillariophyta (diatom belonging to ochrophyta) and Euglenophyta (euglenoids), were recorded during the experiment (Fig. 1). Chlorophyta showed the highest proportion and accounted for $59.4 \%$ of phytoplankton $(17,622$, range 7358-26,930 individuals/L), followed by Bacillariophyta with $17.4 \%$ (5029, range 1198-10,878 individuals/ L), Euglenophyta with $12.2 \%$ (3625, range 1760-5598 individuals/L) and Cyanophyta with $11.4 \%$ (3385, range 1043-5451 individuals/L). At least 13 families were recorded in the Chlorophyta and Cyanophyta phyla 


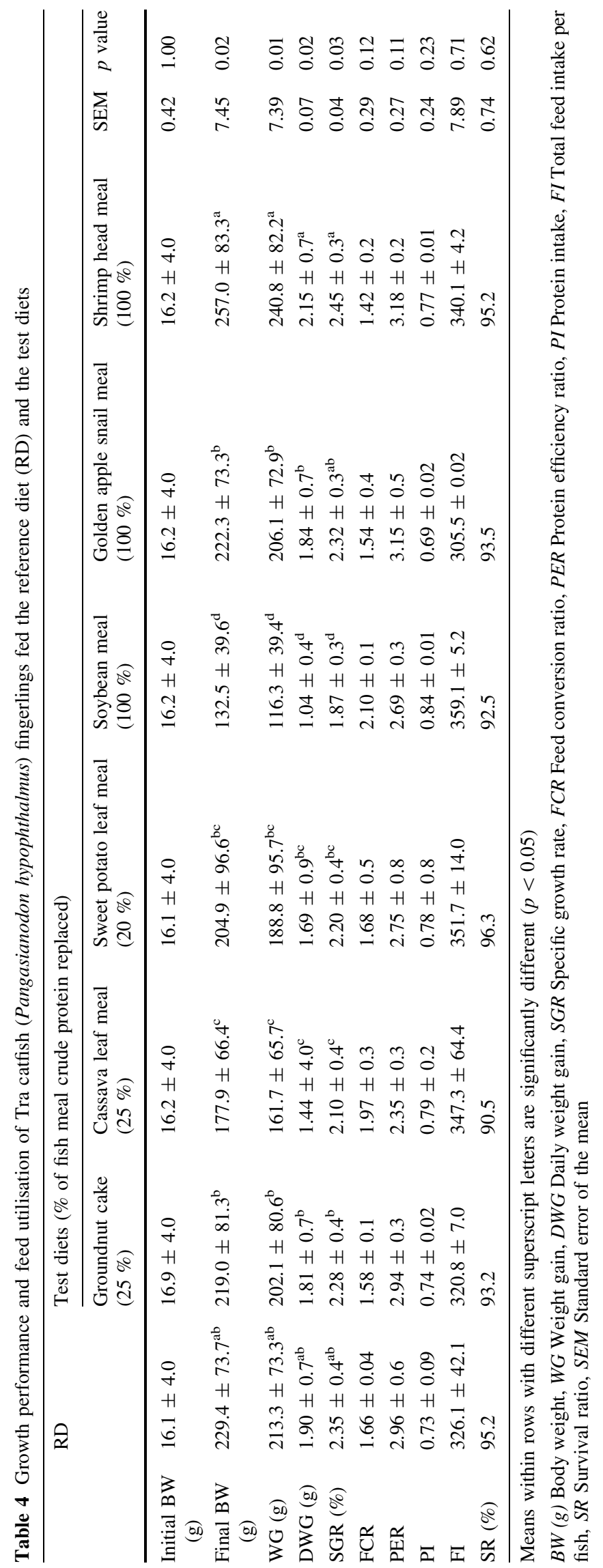




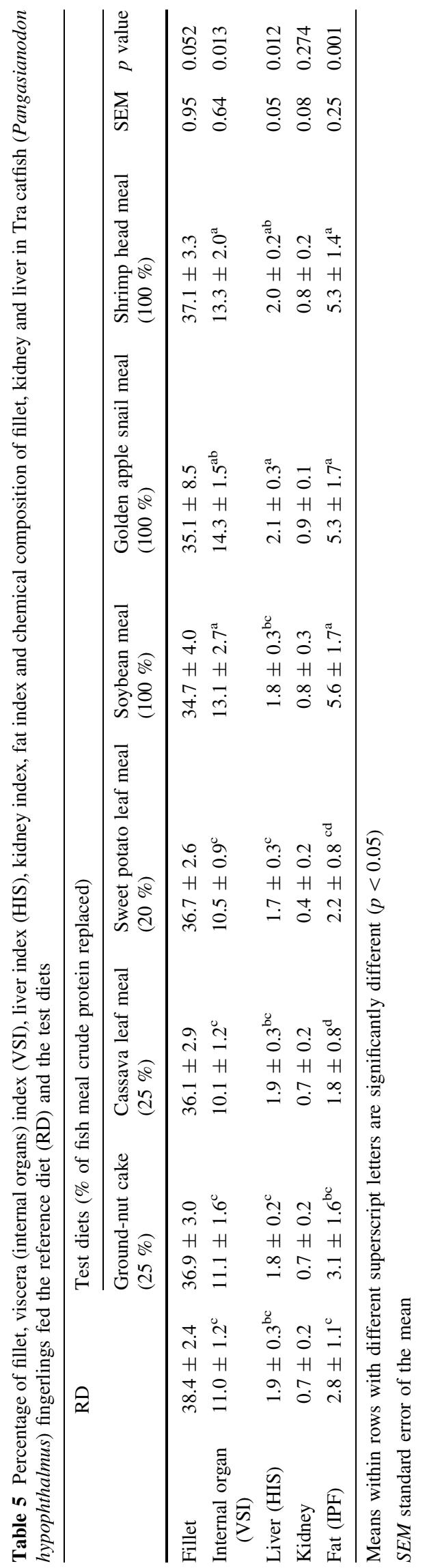




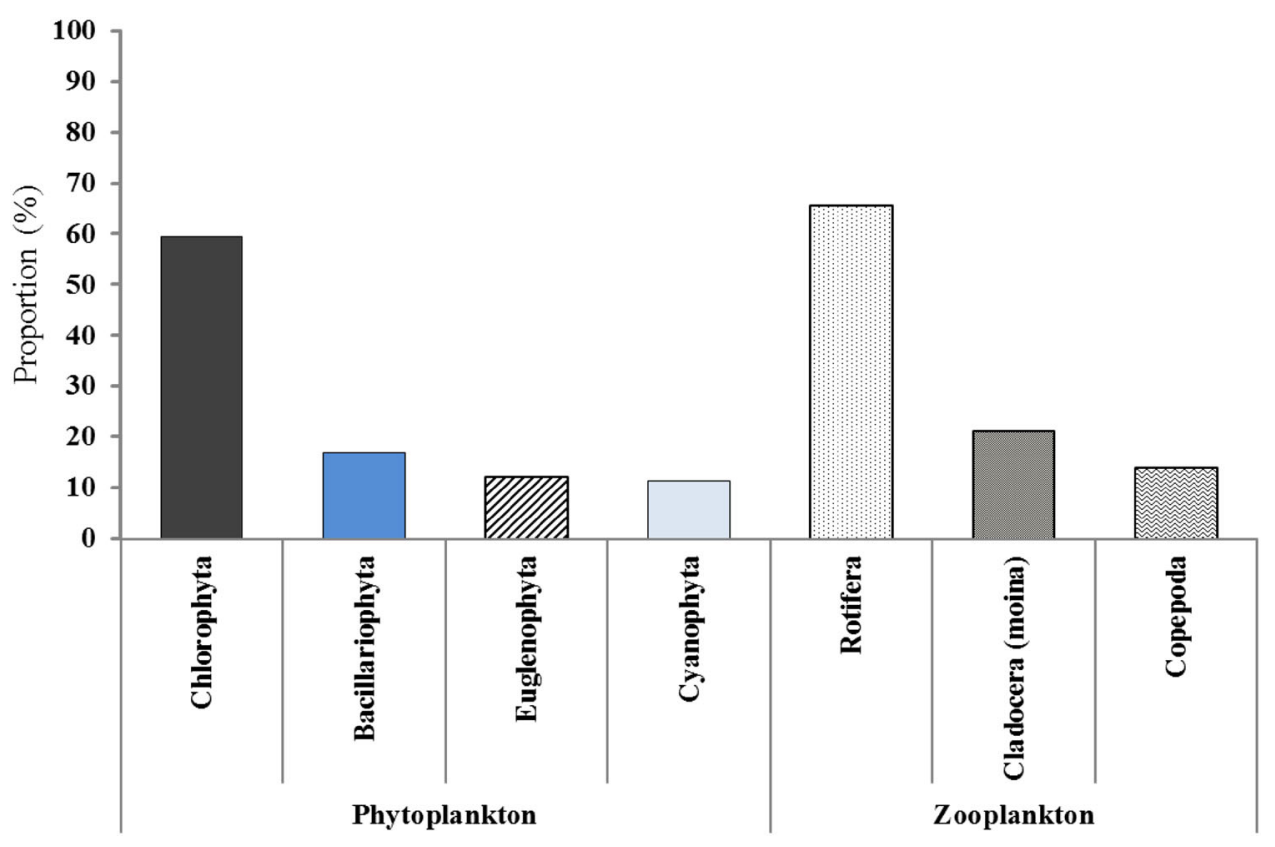

Fig. 1 Proportion (\% of total) of organisms occurring in each phylum of phytoplankton and zooplankton in the pond water used for striped catfish culture over the 16-week experimental period

and there were about six families in the Bacillariophyta phylum and four families in the Euglenophyta phylum. In general, the density of phytoplankton increased as the experiment progressed (Fig. 1).

\section{Zooplankton}

Three main zooplankton groups: Copepoda, Cladocera (monia) and Rotifera were recorded during the experiment (Fig. 1). Rotifera was the most abundant group accounting for $65.1 \%$ of zooplankton (2292, range $766-4767$ individuals $/ \mathrm{mL}$ ), followed by $21.1 \%$ for Cladocera (749, range $147-1442$ individuals $/ \mathrm{mL}$ ) and $13.9 \%$ for Copepoda (489, range $89-1442$ individuals $/ \mathrm{mL}$ ). In general, the density of zooplankton decreased as the experiment progressed (Fig. 1).

\section{Discussion}

The data in the present study on Tra catfish fingerlings, cultured in hapa net cage installed in earthen pond, confirm previous laboratory studies that show that fish meal protein can be replaced with protein from locally available plant and animal ingredients in feed for striped catfish fingerlings without compromising growth performance, feed utilisation or carcass traits ( $\mathrm{Da}$ et al. 2012). The fingerlings were fed identical diets where fish meal CP was replaced with CP from SPLM (20\% replacement), CSLM ( $25 \%$ replacement), GNC (25\% replacement), SBM (100\% replacement), GAPS (100\% replacement) and SHM (100\% replacement). The WG and DWG of fish cultured in hapa net cages installed in earthen pond of current experiment were four to sixfold higher than values reported for Tra catfish and Asian catfish species cultured under other laboratory conditions (Hung et al. 2003; Phumee et al. 2011).

In general, the chemical composition and amino acid profile of test feed ingredients were in good agreement with published data (Hue et al. 2010; Phuc and Lindberg 2000, 2001; Tram et al. 2011; Nguyen et al. 2012). The average CP content of the diets studied was $22.7 \%$ within the range (19-30\% CP) required for normal growth rate in Tra catfish fingerlings, but lower than the range required (27-32\% CP) for maximum growth rate (Hung et al. 2002). The dietary CP content was comparable to that reported for commercial Tra catfish farms, which is on average $26 \% \mathrm{CP}$ (range 20-30\%) for commercial feeds and $22 \% \mathrm{CP}$ (range 17-26\%) for farm-made feeds (Phan et al., 2009). The dietary content (g/kg DM) of arginine (13.2-14.8), 
histidine (3.2-6.4), leucine (16.0-17.6), methionine (4.0-5.9), phenylanine (9.1-10.6) and valine (9.5-10.5) was above the requirements of channel catfish (Wilson et al. 1980). Moreover, the dietary content $(\mathrm{g} / \mathrm{kg} \mathrm{DM})$ of lysine (6.6-9.3), threonine (5.7-7.7) and isoleucine (9.0-10.2) met the requirements of channel catfish (Wilson 1989). Almost all EAA profiles in the diets tested in the present study were high compared with the EAA recommendations for tilapia (Jackson and Capper 1982) and common carp (Schwarz and Kirchgessner 1988).

The poorer growth performance and FCR on the soybean meal diet could be related to disturbed gut function (Nordrum et al. 2000) due to the presence of anti-nutritional factors. It could also be partly due to a lower supply of sulphur-containing amino acids in this diet than in the other diets. The CP and amino acid supply with the cassava leaf meal diet was similar to that with the other diets and the EAA profile was comparable. Although cassava leaves contain cyanogenic glycosides but the content in fresh cassava leaves is reduced by more than $80 \%$ by sun drying and cooking (Hue et al. 2010; Phuc and Lindberg 2001), a negative impact on fish performance cannot be ruled out.

The PER was high in the present study compared with values reported for juvenile African catfish fed plant protein (Fagbenro 2004; Nyina-wamwiza et al. 2007), red-tailed catfish species (Deng et al. 2011) and juvenile Asian catfish species (Hung et al. 2004; Phumee et al. 2011). This indicates that the amino acid supply and amino acid profile in the test diets were adequate for Tra catfish requirements.

The HSI, IPF and VSI indices in present study were lower than those reported previously for Asian catfish species (Hung et al. 2003; Phumee et al. 2011). The HSI index was higher for the groundnut cake, golden apple snail meal and shrimp head meal diets than for the reference diet. Peres and Oliva-Teles (2008) demonstrated a correlation between HSI index and lysine level in the diet of turbot (Scophthalmus maximus) juveniles, with a linear decrease in HSI index with increased dietary lysine level. This relationship could not be confirmed in the present study. It has also been suggested that diets containing high amounts of carbohydrates should result in higher HSI index (Hernández et al. 2007; Hung et al. 2003).

The average water temperature was $28.6^{\circ} \mathrm{C}$, with a pH value of 7.8 (range 6.7-8.2) and a DO content of 7.0 (range 5.4-7.2 mg/L). The average concentrations of BOD $(19.8 \mathrm{mg} / \mathrm{L}), \mathrm{COD}(43.4 \mathrm{mg} / \mathrm{L}), \mathrm{TAN}(0.4 \mathrm{mg} / \mathrm{L})$, $\mathrm{NO}_{2}{ }^{-}(0.1 \mathrm{mg} / \mathrm{L})$ and $\mathrm{NO}_{3}{ }^{-}(0.07 \mathrm{mg} / \mathrm{L})$ were low compared with the limits recommended in National Standards (TCVN 5942 1995). In general, the water quality was good throughout the experiment and the values recorded can be considered low compared with the results of water quality monitoring in Tra catfish farms in the Mekong Delta (Phuong et al. 2010). The average density in water of phytoplankton was 29,661 $(11,359-48,857)$ individuals/L and the average density of zooplankton was 3530 (1002-7651) individuals/L. This was five to threefold higher than the densities of phytoplankton and zooplankton found in river water (Phuong et al. 2010).

\section{Conclusion}

Fish meal protein in feed for Tra catfish (Pangasianodon hypophthalmus) fingerlings can be replaced by protein from locally available plant and animal feed ingredients in effectively compromising growth performance, feed utilisation or carcass traits of fish. However, the extent of replacement will depend on the properties of the individual feed ingredient. Further studies on grow-out fish are warranted to confirm the present findings, and to quantify the impact on fish performance and product quality traits under commercial conditions.

Acknowledgments The authors wish to thank the Sida/SAREC MEKARN ("Mekong Basin Animal Research Network") project for funding the research and a PhD scholarship for Chau Thi Da. The authors also wish to thank the laboratory staff of the National Institute of Animal Husbandry, Ministry of Agriculture and Rural Development, Vietnam, and Mr. Huynh Thanh Phuong and Mr. Le Van Kha, students at the Aquaculture Department, Faculty of Agriculture and Natural Resources, An Giang University, Vietnam, for their support and assistance during this study.

Open Access This article is distributed under the terms of the Creative Commons Attribution 4.0 International License (http:// creativecommons.org/licenses/by/4.0/), which permits unrestricted use, distribution, and reproduction in any medium, provided you give appropriate credit to the original author(s) and the source, provide a link to the Creative Commons license, and indicate if changes were made. 


\section{References}

AOAC (1997) Animal feeds. Chapter 4. In: Cunniff PA (ed) Official methods of analysis vol 1. Association of Official Analytical Chemists International. AOAC, Arlington, pp VI, 1102

Bellinger EG, Sigee DC (2010) Introduction to freshwater algae, in freshwater algae: identification and use as bioindicators. John Wiley \& Sons, Ltd, Chichester, UK, pp 1-285. doi:10.1002/9780470689554.ch1

Bui TM, Lam PT, Ingram BA, Thuy NTT, Gooley GJ, Hao NV, Phuong NT, De Silva SS (2010) Seed production practices of striped catfish (Pangasianodon hypophthalmus) in the Mekong Delta region, Vietnam. Aquaculture 306:92-100

Cacot P, Pariselle A (1999) Description of the sexual cycle related to the environment and set up of the artificial propagation in Pangasius bocourti (Sauvage 1880) and Pangasius hypophthalmus (Sauvage 1878) reared in floating cages and in ponds in the Mekong Delta. In: Legendre M, Pariselle A (eds) The biological diversity and aquaculture of Clariid and Pangasiid catfishes in South East Asia. Proceedings of the mid-term workshop of the 'Catfish Asia Project', 11-15 May 1998. Cantho, Vietnam, pp 71-89

Da CT, Hung LT, Berg H, Lindberg JE, Lundh T (2011) Evaluation of potential feed sources, and technical and economic considerations of small-scale commercial striped catfish (Pangasius hypothalamus) pond farming systems in the Mekong Delta of Vietnam. Aquac Res 44:427-438. doi:10.1111/j.1365-2109.2011.03048.x

Da CT, Lundh T, Lindberg JE (2012) Evaluation of local feed resources as alternatives to fish meal in terms of growth performance, feed utilisation and biological indices of striped catfish (Pangasianodon hypophthalmus) fingerlings. Aquaculture 364-365:150-156

De Silva SS, Phuong NT (2011) Striped catfish farming in the Mekong Delta, Vietnam: a tumultuous path to a global success. Rev Aquac 3:45-73

Deng J, Zhang X, Bi B, Kong L, Kang B (2011) Dietary protein requirement of juvenile Asian red-tailed catfish (Hemibagrus wyckioides). Anim Feed Sci Technol 170:231-238

Edwards P, Tuan LA, Allan GL (2004) A survey of marine trash fish and fish meal as aquaculture feed ingredients in Vietnam. Australian Centre for International Agricultural Research. Working Paper No. 57, pp 1-56

Fagbenro OA (2004) Soybean meal replacement by roquette (Eruca sativa Miller) seed meal as protein feedstuff in diets for African Catfish (Clarias gariepinus, Burchell 1822), fingerlings. Aquac Res 35:917-923

FAO (2010) Fisheries and Aquaculture. Food and Agriculture Organization (FAO) of United Nations. http://www.eoearth.org/ article/Food_and_Agriculture_Organization_(FAO). Accessed 19 June 2011

Halls A, Johns M (2013) Assessment of the vulnerability of the Mekong Delta Pangasius catfish industry to development and climate change in the Lower Mekong Basin. Report prepared for the Sustainable Fisheries Partnership

Hernández MD, Martínez FJ, Jover M, García García B (2007) Effects of partial replacement of fish meal by soybean meal in sharpsnout seabream (Diplodus puntazzo) diet. Aquaculture 263:159-167

Hue KT, Van DTT, Ledin I, Spörndly E, Wredle E (2010) Effect of feeding fresh, wilted and sun-dried foliage from cassava (Manihot esculenta Crantz) on the performance of lambs and their intake of hydrogen cyanide. Livest Sci 131:155-161

Hung LT, Liem PT, Tu HT, Mariojouls C (2002) Comparing growth and protein requirements for fingerlings of three catfish of the Mekong River (Pangasius bocourti, Pangagasius hypothalmus and Pangasius conchophilus). J Aquac Trop 17:325-335

Hung LT, Suhenda N, Slembrouck J, Lazard J, Moreau Y (2003) Comparison of starch utilization in fingerlings of two Asian catfishes from the Mekong River (Pangasius bocourti Sauvage, 1880, Pangasius hypophthalmus Sauvage, 1878). Aquac Nutr 9:215-222

Hung LT, Suhenda N, Slembrouck J, Lazard J, Moreau Y (2004) Comparison of dietary protein and energy utilization in three Asian catfishes (Pangasius bocourti, P. hypophthalmus and P. djambal). Aquac Nutr 10:317-326

Hung LT, Truc LTT, Huy HPV (2007) Case study on the use of farm-made feeds and commercially formulated pellets for pangasiid catfish culture in the Mekong Delta, Viet Nam: Study and analysis of feeds and fertilizers for sustainable aquaculture development. Food and Agriculture Organization of United Nattion-FAO, Fisheries Technical Paper No. 497, pp 363-377

IBM SPSS STATISTIC (2011) IBM SPSS STATISTIC program, version 19 statistical software packages. IBM Corporation, New York

Jackson AJ, Capper BS (1982) Investigations into the requirements of the tilapia (Sarotherodon mossambicus) for dietary methionine, lysine and arginine in semi-synthetic diets. Aquaculture 29:289-297

Kader MA, Koshio S, Ishikawa M, Yokoyama S, Bulbul M (2010) Supplemental effects of some crude ingredients in improving nutritive values of low fishmeal diets for red sea bream, Pagrus major. Aquaculture 308:136-144

Loc V, Bush S, Sinh L, Khiem N (2010) High and low value fish chains in the Mekong Delta: challenges for livelihoods and governance. Environ Dev Sustain 12:889-908

Mamat NZ, Alfaro AC (2014) Evaluation of microalgal and formulated diets for the culture of the New Zealand pipi clam Paphies australis. Int Aquat Res 6:57. doi:10.1007/s40071-014-0057-7

Naylor RL, Hardy RW, Bureau DP, Chiu A, Elliott M (2009) Feeding aquaculture in an era of finite resources. Proc Natl Acad Sci USA 106:15103-15110

Nguyen THL, Ngoan LD, Bosch G, Verstegen MWA, Hendriks WH (2012) Ileal and total tract apparent crude protein and amino acid digestibility of ensiled and dried cassava leaves and sweet potato vines in growing pigs. Anim Feed Sci Technol 172:171-179

Nordrum S, Bakke-McKellep AM, Krogdahl Å, Buddington RK (2000) Effects of soybean meal and salinity on intestinal transport of nutrients in Atlantic salmon (Salmo salar L.) and rainbow trout (Oncorhynchus mykiss). Comp Biochem Physiol Part B 125:317-335 
Nyina-wamwiza L, Wathelet B, Kestemont P (2007) Potential of local agricultural by-products for the rearing of African catfish (Clarias gariepinus) in Rwanda: effects on growth, feed utilization and body composition. Aquac Res 38:206-214

Peres H, Oliva-Teles A (2008) Lysine requirement and efficiency of lysine utilization in turbot (Scophthalmus maximus) juveniles. Aquaculture 275:283-290

Phan TL, Tam BM, Thuy NTT, Geoff GJ, Brett IA, Hao NV, Phuong NT, Silva SSD (2009) Current status of farming practices of striped catfish, Pangasianodon hypophthalmus in the Mekong Delta, Vietnam. Aquaculture 296:227-236

Phuc BHN, Lindberg JE (2000) Ileal and total tract digestibility in growing pigs given cassava root meal diets with inclusion of cassava leaves, leucaena leaves and groundnut foliage. Br Soc Anim Sci 17:301-308

Phuc BHN, Lindberg JE (2001) Ileal apparent digestibility of amino acids in growing pigs given a cassava root meal diet with inclusion of cassava leaves, leucaena leaves and groundnut foliage. Anim Sci 72:511-517

Phumee P, Wei WY, Ramachandran S, Hashim R (2011) Evaluation of soybean meal in the formulated diets for juvenile Pangasianodon hypophthalmus (Sauvage, 1878). Aquac Nutr 17:214-222

Phuong NT (1998) Pangasius catfish cage aquaculture in the Mekong Delta, Vietnam: current status and study for feeding improvement. College of Aquaculture and Fisheries, Can Tho University, Vietnam, Doctoral thesis no. 1999 (Library of Can Tho University), p 29

Phuong NT, Sinh LX, Thinh NQ (2007) Economics of aquaculture feeding practices: Vietnam. FAO Fish Tech Pap Rome 505:183-205

Phuong NT, Ut VN, Tung VT, Hang NTT, Lien NTK, Oanh DTH, Huong DTT, Morales EJ (2010) Water quality monitoring in striped catfish (Pangasianodom hypophthalmus) farms in the Mekong Delta, Vietnam. College of Aquacultrue and Fisheries, Can Tho University, Vietnam, Sustainable Fisheries Partnership, pp 1-19. http://media.sustainablefish.org/Final\%20report_ Water\%20Quality2009_final.pdf. Accessed 29 May 2012

Schwarz FJ, Kirchgessner M (1988) Amino acid composition of carp (Cyprinus carpio L.) with varying protein and energy supplies. Aquaculture 72:307-317

Stirling HP (1985) Chemical and biological methods of water analysis for aquaculturists. Institute of Aquaculture, University of Stirling, Stirling, p 117

Suthers IM, Rissik D (2008) Plankton: a guide to their ecology and monitoring for water quality. CSIRO Publishing, Collingwood, pp 1-273

TCVN 5942 (1995) National standard (TCVN 5942-1995). Ministry of Fisheries, Hanoi. Sector Standard (TCVN 5942)

Tram NDQ, Ngoan LD, Hung LT, Lindberg JE (2011) A comparative study on the apparent digestibility of selected feedstuffs in Hybride catfish (Claria macrocephalus $\times$ Clarias gariepinus) and Nile tilapia (Oreochromis niloticus). Aquac Nutr 17:636-643

Van Soest PJ, Robertson JB, Lewis BA (1991) Method of dietary fiber, neutral detergent fiber, and nonstarch polysaccharides in relation to animal nutrition. J Dairy Sci 74:3583-4597

Vázquez-Ortiz FA, Caire G, Huguere-Ciapara I, Hernández G (1995) High-performance liquid chromatographic determination of free amino acid in shrimp. J Liq Chromatogr 18:2059-2068

Wilson RP (1989) Amino acids and proteins. In: Halver JE (ed) Fish nutrition, 2nd edn. Academic Press, New York, pp 111-151

Wilson RP, Poe WE, Robinson EH (1980) Leucine, isoleucine, valine and histidine requirements of fingerling channel catfish. J Nutr 110:6273 